\title{
床塵埃中のカビとダニアレルゲン量
}

第 1 報 集合住宅の場合

FUNGI AND MITE ALLERGEN IN HOUSE DUST ON FLOOR

First Report Case of collective houses

\author{
菅原文子* \\ Fumiko SUGAWARA
}

\begin{abstract}
This is to report the result of measurements carried out in two collective house buildings in Tohoku District on fungi and mites allergen in house dust. Fungi were counted after cultivation on Agar plates. Mites allergens were determined for Derf I, Derp I and Der II by immuno-chemical method. The fungi counts in February and September in A building showed no significant difference. Derp I did not have a definite tendency and Derf I and Der II showed very high values in September compared with those in February. The correlation between mites allergen and fungi was not observed and the correlation between mites allergen, fungi and the temperature, humidity was not found either.
\end{abstract}

Keywords : house dust, fungi, mite allergen, temperature and humidity, surface temperature, correlation 室内塵, カビ, ダニアレルゲン, 温湿度, 表面温湿度, 相関関係

\section{緒 言.}

近年, アレルギー疾患の患者が増加し，住居内に生息， 増殖するダニ，カビがアレルギー体質の人にとって，ア レルゲンとなっている例が多く11,2)，ことに，ダニアレ ルゲンについては，増加する傾向にある2!。

居室内に生息するダ二, カビは, その増殖条件となる 温湿度条件が近似しており, 暖房温度あるいは生活パ ターンによって, 同一の住戸内で両者が同時に繁殖して いることは，容易に予測がつく。

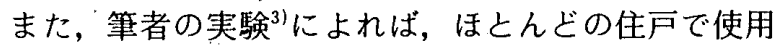
されている室内床仕上材の兽は, カビの成長に適した性 質を有しており, 室内でカビの増殖が予測される。近年, 多数の住戸で使用されている床仕上材としてのカーペッ トは，その中に堆積した塵埃に生息するダ二が温湿度が 適したとき増殖し，清掃によっても塵埃が完全に除去で きないことから, 室内でのダ二数の増加が考えられる。

筆者は，同一条件下で増殖するカビとダニを，各戸で 収集した床塺埃中から, 単位重量中のカビコロニー数と ダニアレルゲンの定量を行い, それぞれ相関, 季節変動, 温湿度との関係を求めたので報告する。

\section{1. 在来の研究}

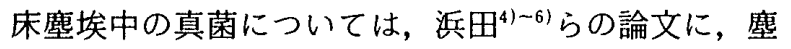
埃中の真菌の数, 季節的消長, 同定結果が発表されでお ク,ダニとの関係も発表されている。

また，坂口゙は空気中の浮遊塵埃をサンプリングして， 浮遊塺埃中のダニアレルゲン量について発表している。 しかし，居室内にほぼ同一の温湿度条件で生息するカビ. とダニアレルゲンとの関係は, 温湿度の条件との関係と ともに，明らかにされていない。

\section{2. 実験概要}

1) 测定住戸 東北地方における民間の集合住宅 2 棟 (以下A棟およびN棟)（表一1）について，アンケート を配布し，各戸の全床面積の床塵埃を同一の電気掃除機 で収集した。

完成後の経過年数は $\mathrm{A}$ 棟は 3 年, $\mathrm{N}$ 棟は 2 年である。

表一1 測定対象建物概要

\begin{tabular}{c|c|c|c|c}
\hline & 構造 & 延面積 & 階数 & 住戸数 \\
\hline A 棟 & RCS造 & $7808.05 \mathrm{~m}^{2}$ & 13 階 & $103 \bar{戸}$ \\
\hline N 棟 & RCS造 & $4351.6 \mathrm{~m}^{2}$ & 9 階 & 57 户 \\
\hline
\end{tabular}



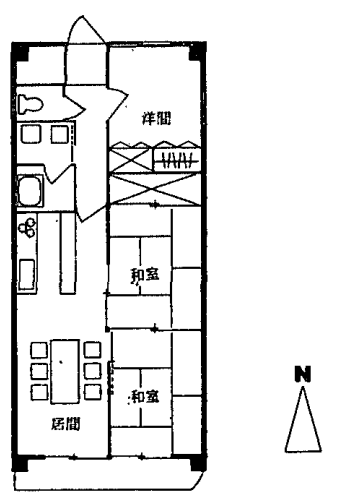

图一1 a A 棟測定住戸の 1 例

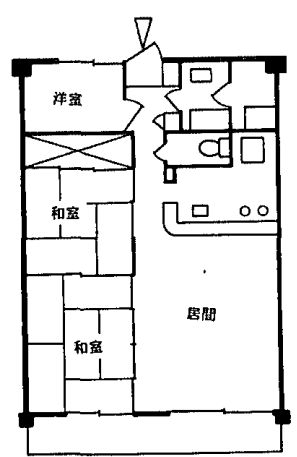

図一1 b N 棟測定住戸の 1 例

アンケート調查は, $\mathrm{A}$ 棟では 2 月, 9 月の 2 回, 全戸数 103 戸のうち 35 戸， N棟では， 9 月のみ 70 戸中 42 戸で 回収した。これらの住戸のうちA棟では 2 月に 19 戸，9 月に 12 戸, N棟では 18 戸において床塵埃収集を行っだ。 図一 $1 \mathrm{a}$ に $\mathrm{A}$ 棟, 図一 $1 \mathrm{~b}$ に $\mathrm{N}$ 棟の平面図の例を示す。 これらの集合住宅は，各戸の平面がほとんど同一である ので，それぞれを代表できるものと思われる。

2）アンケート アンケートについては，家族構成，入 居時期, カビについての関心の有無, アレルギーの有無, 掃除回数などについて設問を行った。回収率は $70 \%$ 前 後であった。

3）培地 一般真菌数を求めるために PDA 培地を作成 し，そのほかに浜田 ${ }^{4}$ の提唱する乾燥菌をよく発生させ る DG 18 培地を作成, 発生コロニ一数の比較を行った。

4）應埃中のカビコロニー計数 1 戸で収集した掃除機 の紙パックの重量を計測し，その中から0.5 g の塵埃を 採り, 減菌水で 100 倍に希釈し, よく振騰した後, 上澄 液から白金耳で 2 種類の培地上に植え付け培養して，発 生コロニー数を計測した。

5）ダニアレルゲン定量 紙パック内の塵埃を化学免疫 法によって，戦後著しい増加をみせたチリダニ科息の Derf I (Dermatophagoides farinae), Derp I (Dermatophagoides pteronyssinus), Der II について定量を行っ た。

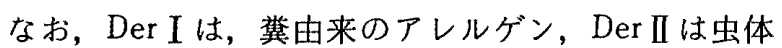
由来のアレルゲンであるとされている。

6) 温湿度測定 室内温湿度はアスマン温度計により, 各戸共居間中央床上 $120 \mathrm{~cm}$ の点で，サンプリング前 1 回の測定を行った。床面温湿度は, VAISALA 社製 HM 34 の温湿度計を用いて, 室中央付近 1 か所で, 室 内温湿度測定後直ちに測定した。

7）真菌の同定 2 種類の培地に発生した真菌をそれぞ れの培地に 1 種類の菌になるまで分離を繰り返した後, PDA の斜面培地に植え付け，一定期間真培養した菌を 使用して、スライドカルチャー法"11によよって同定を行っ た。

\section{3. 結 果}

1) アンケート結果

家族人数平均 3.2 人，カビについての関心は， $86 \%$ の家族で関心をもっている。掃除回数について 1 日 1 回 が最も多く $65 \%$ を占めている（図一3）。アレルギー疾 患の有無についての質問には，入居後発症した人はない が，アレルギー性鼻炎が最も多かった。なお，皮膚炎も 同じ率を示しているが, 空気污染という関係から，鼻炎 のみを対象とした。図一2, 図一4-1２ に結果を示す。

2) 室内温湿度

集合住宅であるため, 各戸の值に大きな変化がなかっ た。

$\mathrm{A}$ 棟の測定住戸全体では，2 月では，室内温度は平均 $18.7^{\circ} \mathrm{C}$ (標準偏差 $2.0^{\circ} \mathrm{C}$ ), 相対湿度は $52 \%$ （標準偏

\begin{tabular}{|c|c|c|}
\hline & \begin{tabular}{|l|l|} 
度数 $\%$ CUL\% \\
\end{tabular} & $20 \quad 40 \quad 60 \quad 80100$ \\
\hline はい & 36.86 & \\
\hline いいえ & \begin{tabular}{l|l|l}
6 & 14 & 100
\end{tabular} & \\
\hline 無回答 & 0,0100 & $-1-1-1-1-1$ \\
\hline 合計 & 42100 & \\
\hline
\end{tabular}

図一2 アンケート結果 カビについての関心の有無についての 質問

CUM：累積度数分布

\begin{tabular}{|c|c|c|c|}
\hline & 度数 $\%$ & & $20 \quad 40 \quad 60 \quad 80100$ \\
\hline 一旦数回 & \begin{tabular}{|l|l|}
2 & 5 \\
\end{tabular} & $5^{m}$ & \\
\hline 一日一-回 & \begin{tabular}{|l|l|}
28 & 65 \\
\end{tabular} & 70 & 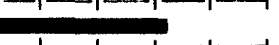 \\
\hline 二 三日に一回 & 14 & $84=$ & E \\
\hline 四〜五日に一回 & 3 & $91=$ & \\
\hline 週一回 & 4 & $100=$ & \\
\hline 合計 & $43|100|$ & & \\
\hline
\end{tabular}

図一3 アンケート結果 掃除の回数についての質問 CUM：累積度数分布

\begin{tabular}{|c|c|c|c|}
\hline & 度数 & $\% \quad$ cum & $20.40 \quad 60 \quad 80100$ \\
\hline いる & 19 & 45 & \\
\hline いない & 23 & \begin{tabular}{l|l|}
55 & 100 \\
\end{tabular} & E \\
\hline 合計 & 42 & 100 & \\
\hline
\end{tabular}

図一-1 アンケート結果 アレルギー䓡患についての質問 CUM : 累積度数分布

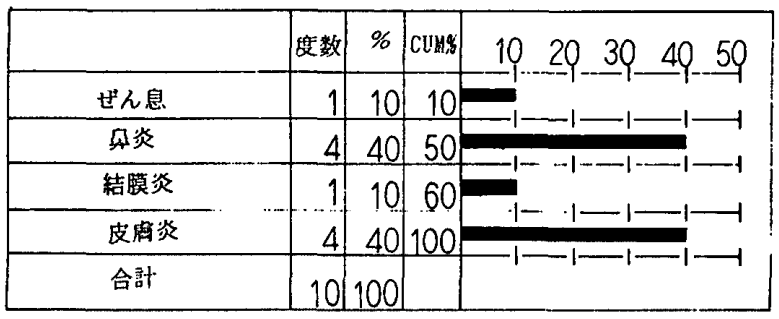

图一-4 アンケート結果 アレルギ一疾患の種類 CUM : 累積度数分布 
差 $2 \%$ ), 休表面温度は $17.0^{\circ} \mathrm{C}$ (標準偏差 $1.8^{\circ} \mathrm{C}$ ), 相 対湿度は $50 \%$ （標準偏差 $6 \%$ ）であった。9月の測定 では, 平均室内温度 $25.4^{\circ} \mathrm{C}$ (標準偏差 $1.0^{\circ} \mathrm{C}$ ), 相対湿 度 $65 \%$ (標準偏差 $6 \%$ ), 床表面温湿度は，それぞれ $25.4^{\circ} \mathrm{C}\left(0,9^{\circ} \mathrm{C}\right), 61 \%$ (標準偏差 $\left.7 \%\right)$ で，9月は温 度が高いにもかかわらず,相対湿度が高い傾向であった。

$\mathrm{N}$ 棟の測定住戸全体では，9月のみであるが，室内平 均温度 $24.6^{\circ} \mathrm{C}\left(1.3^{\circ} \mathrm{C}\right)$, 相対湿度 $67 \%$ (標準偏差 $8 \%$ ) であり，床表面温湿度は $23.3^{\circ} \mathrm{C}$ (標準偏差 $1.7^{\circ} \mathrm{C}$ ), $68 \%$ （標準偏差 $8 \%$ ) であった。室内温湿度と床表面温湿度 は近似した值を示している。なお, 両棟とも, 経時変化 は計測していない。

3）塺埃中のカビコロニー数

前述の方法でペトリ皿の培地上に発生したコロニー数 は, PDA 培地, DG 18 培地それぞれを計数した結果, 住戸によりかなりばらつきがあることがわかった。

$\mathrm{A}$ 棟の 2 月の結果は, $\mathrm{PDA}$ 培地で平均 430 個, $\mathrm{DG}$ 18 培地で 404個である。同じく $\mathrm{A}$ 棟の 9 月の結果は PDA 培地で 200 個, DG 18 培地で 472 個の結果を得た。 一方, N 棟の結果は, PDA 培地で 580 個, DG 18 で 588 個と同一月の比較では，A棟よりカビコロニーが多 い結果を得た。特に PDA 培地では 2 倍強のコロニー数 であった。

室内温湿度とカビコロニー数の関係：図一 5 に示すよ うに, $\mathrm{A}$ 棟の 2 月测定では両培地共に室内温度 15 $20^{\circ} \mathrm{C}$ 付近にコロニー発生がみられるが，この測定時の 室内温度の範囲である。9 月測定では $25^{\circ} \mathrm{C}$ に集中して いるが, 室内温度変化の幅が狭く室内温度の範囲内でコ ロニ一の発生をみたが, 真菌の培養温度が $25^{\circ} \mathrm{C}$ である ことから，繁殖に最適であったと思われる。

朱表面温度との関係: 発生温度の幅が $24 \sim 26.5^{\circ} \mathrm{C}$ に ひろがる傾向があるが（図一6），いずれも測定時の温度 幅内 $\left(15 \sim 30^{\circ} \mathrm{C}\right)$ で, コロニ一の発生があり, 真菌の 增殖の適温範囲内の室温, 林表面温度内で十分に成育し ているものと思われる。

相対湿度がカビコロニー数に与える影響：室内湿度で

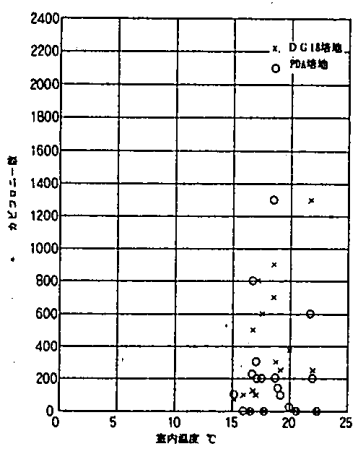

图一5-1 室内温度とカビコロ ニー数の関係 $(2$ 月 $\mathrm{A}$ 棟)

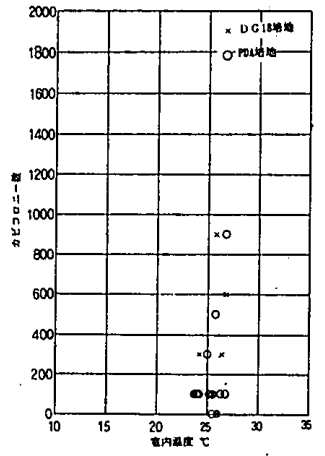

図一-2 室内温度とカビコロ ニ一数の関係 (9月A棟)
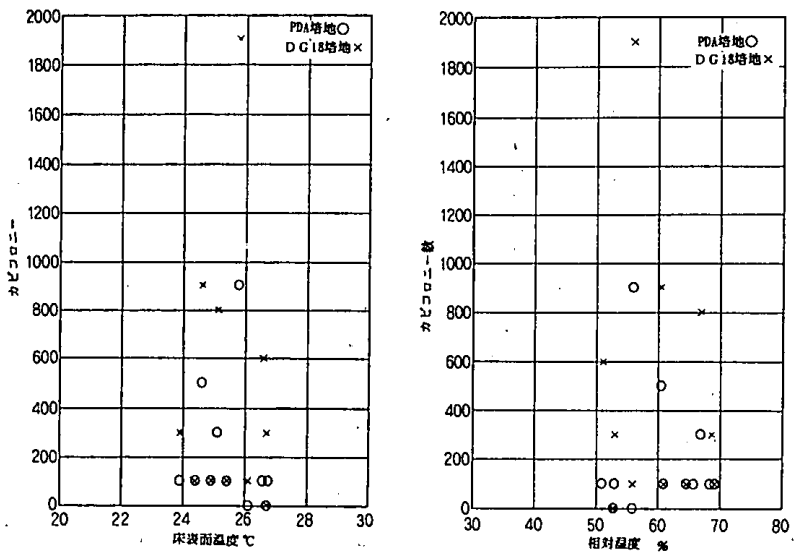

図一6床表面温度とカビコロ ニー数の関係 $(9$ 月 $\mathrm{A}$ 棟)

图一7 床表面湿度とカビコロ 二一数の関係 (カーペット) (A棟 2月)

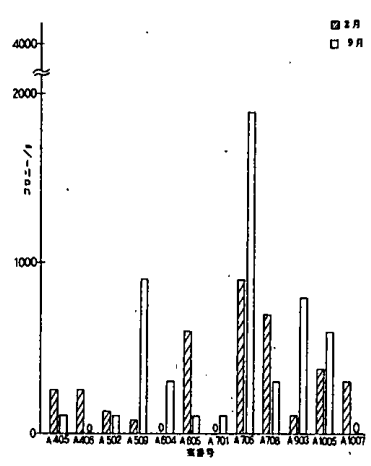

図一8 カビコロニー数の 2 月 と9月の比較 (DG.18 培地) (A 棟)

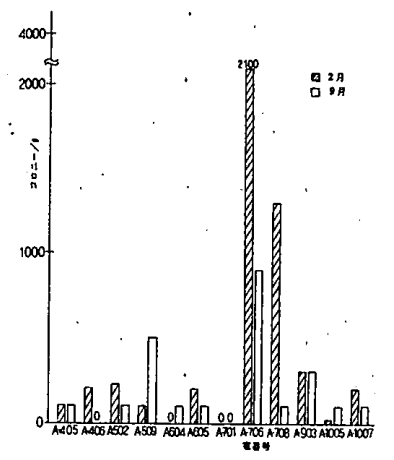

図一9 カビヨロニ一数の 2 月 と 9 月の比較 (PDA 培地) (A棟)

は明らかではないが，図一7に示すように，床表面湿度 では測定時の範囲内の 50 70\%付近で多くの発生がみ られる。

季節的なコロニー数の変動：測定対象 A 棟において は，各住戸によって異なり，必ずしも冬季のカビが少な いとはいえないようであるが，DG 18 培地に成育する といわれる乾燥菌については, 9 月が多い傾向がある(図 -8 , 図一9)。

4）塺埃中のダニアレルゲン

ダニアレルゲン量は季節的変化が大きいといわれる が，本測定が 2 月と 9 月という最もダ二の诚少する時期 と最も増加する時期に行うことができた。

この 2 回の測定で集合住宅 $\mathrm{A}$ 棟の場合，同一住户での 結果を比較してみると, Derp I では 9 月が多い場合も あるが，全体として顕著な傾向とは言えない。一方， Derf I，Der II は，2月に比して，9月のアレルゲン量 は非常に多く，ことに，Derf Iにおいてその傾向か顕著 である。図一10, 図一11, 図一12に結果を示す。ダニ アレルゲンについては，9月に增加するといわれている が8), 今回の測定結果から, Derf I, Der IIについては, その傾向が確認された。 


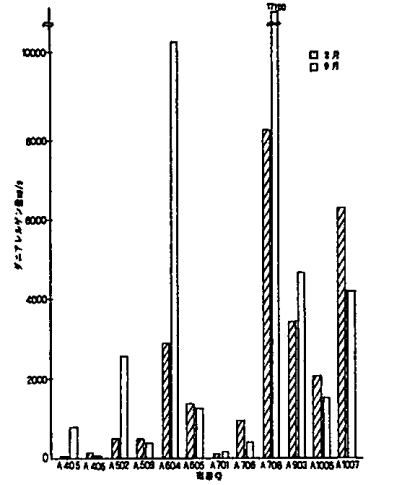

图一10 ダニアレルゲン量の 2 月と 9 月の比較 (DerpI ) (A棟)

室内の温湿度とダニアレ ルゲン量との関係：2月の $\mathrm{A}$ 棟の測定結果から図一13 に示すように, 室内相対温 湿度との関係が明らかであ り，50\%前後にアレルゲ ン量が多いのがわかる。し かし, 絶対湿度ではばらつ きが大きく，関係は見いだ せない（図一14）。

また，床表面相対湿度で

$$
\text { 图 }
$$

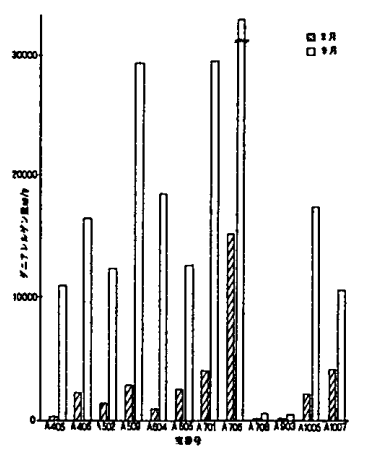

図一11 ダニアレルゲン量の 2 月と 9 月の比較 (Derf I )

(A棟)

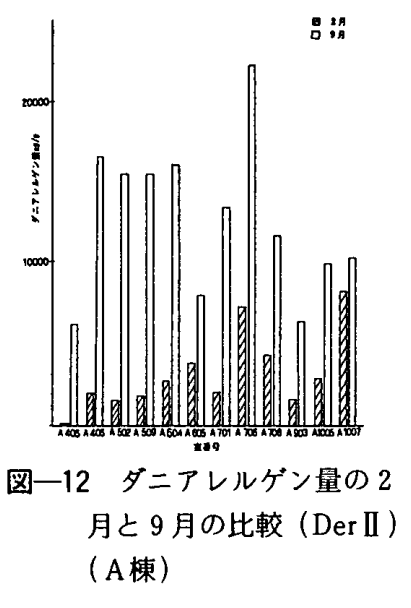

は, 図一15に示すように，

$\mathrm{N}$ 棟（9月）の場合, 測定值が得られた 60 - $80 \%$ の笧 囲にアレルゲンの分布がみられるが, 絶対湿度について は明らかな関係は晃いだせない。

室内温度とダニアレルゲン量の関係は, ほとんど関係 がないようであるが，A棟の 2 月測定の結果から床表面 温度との関係では図一 16 , 図一 17 に示すように, $18^{\circ} \mathrm{C}$ を中心として, アレルゲン量が多く, それ以下では，し だいに減少していることがわかった。

$\mathrm{A}$ 棟およびN棟の 9 月の測定結果からは, 室内温度, 床表面温度のいずれとも関係は明らかではなかった。

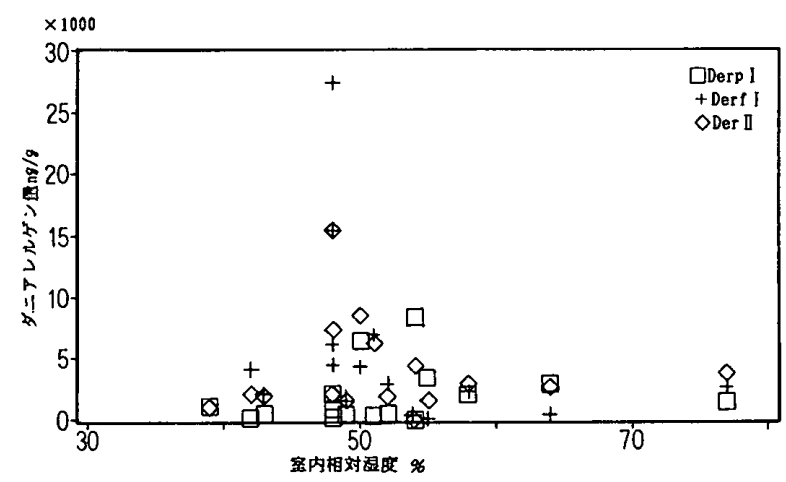

図一13 室内相対湿度とダニアレルゲンの関係（A棟 2月）

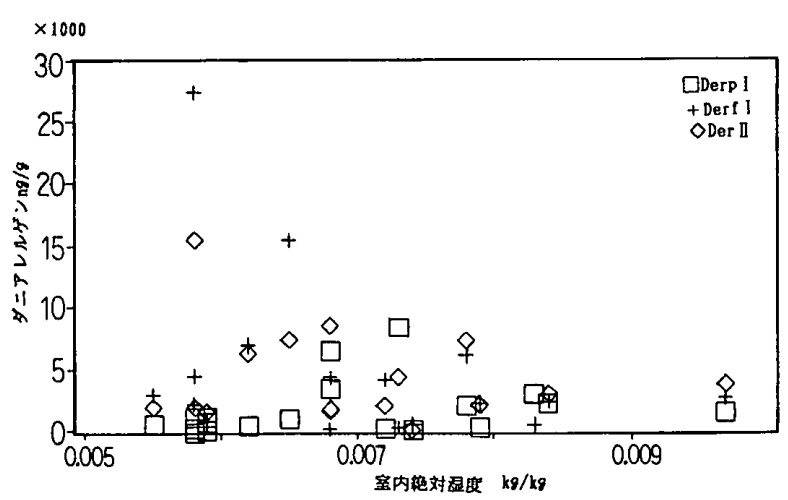

図一14 室内絶対湿度とダニアレルゲンの関係（A 棟 2 月）

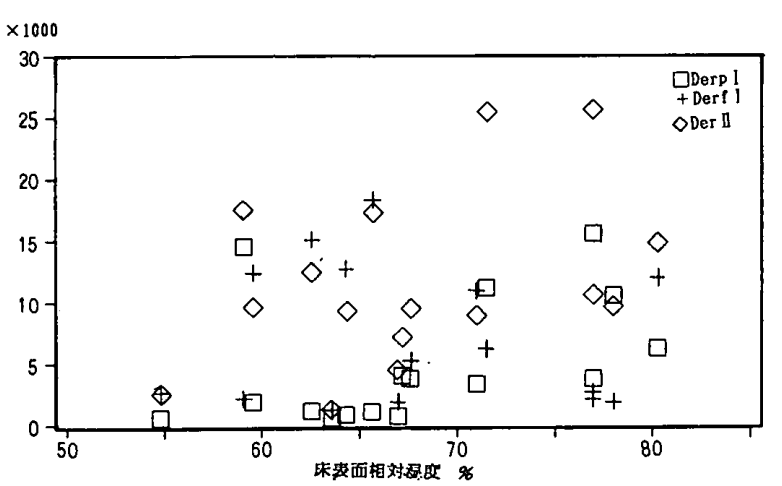

図一15休表面相対湿度とダニアレルゲン量の関係 ( $\mathrm{N}$ 棟 9 月 $)$

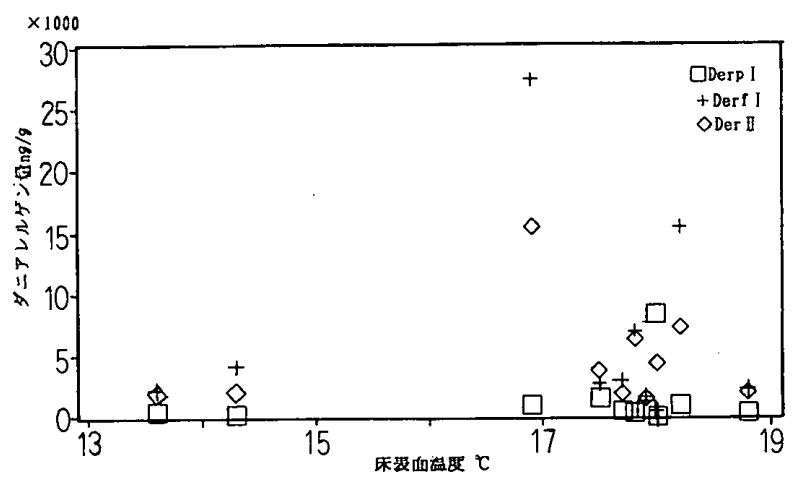

図一16 床表面温度とダニアレルゲン量の関係 (畳) (A棟 2 月)

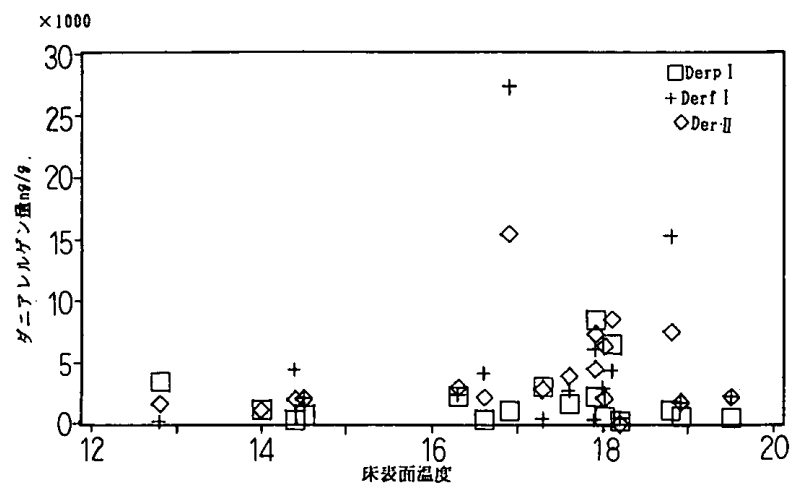

図一17 床表面温度とダニアレルゲン量との関係（カーペット） (A棟 2月) 


\section{5) 同定結果}

測定対象の $\mathrm{A}$ 棟， $\mathrm{N}$ 棟で捕集した真菌を単一の菌種に なるまで分離を繰り返した後, 前述の方法で顕微鏡によ り同定した結果，いずれからもAspergillus 属, Penicil lium 属, Cladosporium 属が多く検出された。

\section{4. 考 察}

真菌の増殖に適した環境は, 温度は $25^{\circ} \mathrm{C}$ を中心とし て，15 30 $0^{\circ} \mathrm{C}$ で良く增殖することが知られているが, 菌によっては，湿度条件が満たされれば， $5^{\circ} \mathrm{C}$ の低温か ら $35^{\circ} \mathrm{C}$ まで増殖可能である ${ }^{31}$ 。湿度は菌によって適温 が異なるが，60\% 以上であれば，ほとんどの菌は增殖 する。このことは，一般家族の生活の温湿度条件下でい つでもどこでも増殖する可能性を持っている之いえる。

ダニの生息, 增殖についても真菌とほぼ同程度の室内 温湿度条件である。この二つの微生物が室内の温湿度の 影響をうけて增殖するのか, 生息場所として問題になっ ている床面, あるいは, 疊, カーペットの内部の条件に よるものかは，いまだ明らかではない。しかし，室内の 湿度に関しては，床面とほぼ平衡状態になると考えられ る。温度に関しては, 暖房方法等によっては, 室内温度 の垂直分布は，床面で低くなるのが一般的である。

本測定では, 室内温湿度を測定すると同時に床面の測 定も行った。また, 相対湿度が增殖に影響するか, 絶対 湿度の影響を受げるかを確かめた。

測定結果からみると, 真菌の増殖は, 室内温度が関係 していると思われ， $\mathrm{A}$ 棟においては，2月に $15 \sim 20^{\circ} \mathrm{C}$ の範囲に，9月は $25^{\circ} \mathrm{C}$ に集中しているが，床表面温度 との関係はみいだせない。いずれの場合も，塺埃 $0.5 \mathrm{~g}$ 中の真菌が平均値で 400 500 コロニ一, 最高では 4100 コロニーと非常に多いことが明らかになった。浜田ら ${ }^{4) .5)}$ の結果と比較すると, 平均值では少ないが, ばらつきが 大きく，多い場合では，同じような結果を得た。

集合住宅 $\mathrm{A}$ 棟の 2 月と 9 月の真菌コロニー数を比較し てみると，必ずしも 9 月の值が高い結果はでなかった。 集合住宅であるために，外気温の影響は 1 户建住宅に比 して受けにくく, 室内気温の変化が小さいのが原因かと 思われるが, 要因は明らかでない。

ダニアレルゲンについては, Derf I, Derp I, Der II 共に $\mathrm{A}$ 棟の 2 月の測定結果では, 床面表面温度 $18^{\circ} \mathrm{C}$ 付 近に分布している。A 棟, $\mathrm{N}$ 棟両集合住宅とも 9 月の測 定では, ばらついているようにみえるが, 室温の範囲が, $20 \sim 27^{\circ} \mathrm{C}$, 床表面温度 $20 \sim 26^{\circ} \mathrm{C}$ であるため, この室温 の範囲にダニアレルゲンの分布があるかとも思われる。 冬期と秋期で環境に適応して生息適温が異なるのかもし れない。

湿度に関しては, A 棟の 2 月の測定結果からは, 室内 湿度との関係かみられ, 室内相対湿度 $50 \%$ 付近にダニ

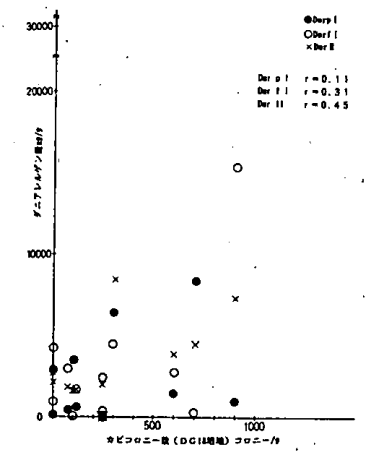

図一18 カビコロニー数とダ二 アレルゲン量との関係 (A棟 2 月)

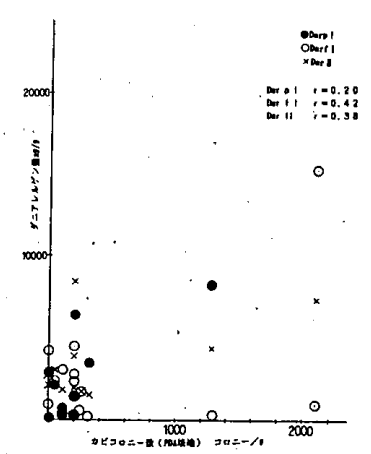

図一19 カビコロニー数とダニ アレルゲン量との関係 (A棟 2 月)
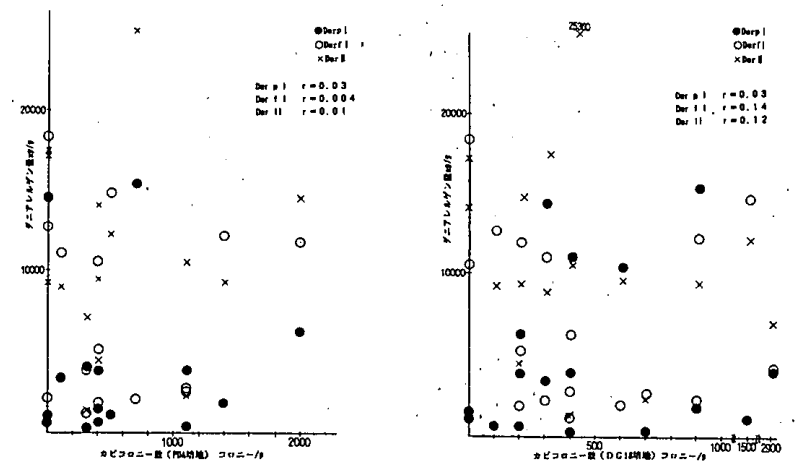

図一20 カビコロニ一数とダニ アレルゲン量との関係 ( $\mathrm{N}$ 棟 9 月)

図一21 カビコロニー数とダニ アレルゲン量との関係 ( $\mathrm{N}$ 棟 9 月)

アレルゲンが分布し，床表面湿度は関係がみられない。 2 月の $\mathrm{A}$ 棟, 9 月の $\mathrm{A}$ 棟, $\mathrm{N}$ 棟ともに温湿度との関係は とくにみいだせないが, 湿度では相対湿度, 床表面湿度 いずれも $60 \%$ 以上に分布が多いようである。

ダニアレルゲン量を集合住宅 $\mathrm{A}$ 棟の 2 月と 9 月の結果 から比較を試みると， 2 月に比して 9 月が多いのが明ら かであるが，Derp I は，他のアレルゲンと比較すると， 2 月と 9 月の差は小さい。Derf I , Der II は 2 月と 9 月 のアレルゲン量は 9 月がはるかに多く, とくに, Derf I ではその差は顕著である。

当初の目的であったカビとダニアレルゲンとの関係 は，図一18，19，20，21に示すように特筆すべき関係は みいだせなかった。測定対象が集合住宅であるために， 各戸の温湿度にほとんど変化がなく, カビコロニー数, ダニアレルゲン量は生活パターンにより各戸で大きく異 なり，ばらつきが大きいためと思われる

収集した塺埃重量, 掃除回数, 居住年数等とカビ量, ダニアレルゲン量とは関係がなかった。

結果的に 1 年間の最もダニアレルゲン，カビの少ない 季節と最も多い季節に測定を行ったが，ダニアレルゲン 量は室内相対湿度と関係し, カビは室内温度と関係をも ち, 生息する床表面の温湿度との関係が見いだせないの かは，今回の測定結果からは不明であった。 
5. まとめ

1. 東北地方の 2 棟の集合住宅において，カビおよびダ ニアレルゲンと環境条件の関連を知るためにアンケート 調查および実測を行った。

2. 調查した 2 月・ 9 月の測定の範囲の室内温湿度条件 の下では, PDA 培地, DG-18 培地ともにコロニーの発 生をみた。

3. 床表面温度とダニアレルゲンとの関係は，A 棟 2 月 の測定結果からは, $18^{\circ} \mathrm{C}$ 付近に強そうであることが分 かった。

4. A 棟における 2 月および 9 月の測定值から, Derp Iでは特徵的な違いはなく, Derf I， Der IIでは 2 月に 比して9月が多い。

5. 室内の絶対湿度, 床表面絶対湿度とダニアレルゲン との明らかな関係は見いだせなかった。

6. ダニアレルゲンとカビコロニーとの相関関係は， A 棟 $\mathrm{N}$ 棟のいずれの測定值からも認めなかった。

謝 辞

本研究に際して,ダニアレルゲン定量について, 杏林 大学保健学部宮沢 博氏, カビの同定について, 郡山女 子大学助教授諸岡信久氏のご協力を得たことに謝意を表 する。
注

1) 鶴田 理：カビのスライドカルチャー, p. 331, 微生物の 分離法, R \& D プランニング (1986)

\section{引用文献}

1）小野俊孝ほか：喘息児家族における室内浮遊塺の喘息発 作に対する影響・アレルギー 36（11） pp. 976〜983, 1987

2)蝶名林直彦：アレルゲンの要因, アレルギー性疾患は增 えているか, 調查結果と原因（宮本昭正編）pp. 58～61, 1987

3）菅原文子：建築材料に増殖するカビ，日本建築学会計画 系論文報告集，第 441 号，pp. 9 14，1992

4）沃田信夫ほか：室内塵埃中の真菌数に影響を与える要母, アンケート調查結果より，防菌防微誌Vol. 18, No.6, pp. $279 \sim 284,1990$

5）浜田信夫ほか：室内塺埃中の真菌相に及ぼす種々の要因 の影響，大阪市環境科学研究所報告，第 52 集，1988

6) 浜田信夫ほか：Seasonal change in the fungal flora of house dust. Trans. Mycol. soc. Japan 32 : pp. 45 53, 1991

7) 坂口雅弘ほか：Measurment Allergens Associated with Dust Mite Allergy II Concentrtion of Airborne Mite Allergens (Der I and Der II) in the House. Current Opinion in Lmmunology 2 pp. 525 -530, 1990

8）高岡正敏：住環境の変化,ダ二数の関係，アレルギー性 疾患は増えているか, 調查結果と原因（宮本昭正編）， pp. $54 \sim 57,1987$

(1992 年 8 月 19 日原稿受理, 1993 年 3 月 8 日採用决定) 